\title{
KOLLEKTIIVINEN ASIANTUNTIJUUS JA JAETUT TIETOKÄYTÄNNÖT
}

\begin{abstract}
Kollektiivisessa asiantuntijuudessa yhdistyvät yksilölliset, yhteisölliset ja verkostoituneet ulottuvuudet. Se näyttäytyy sosiaalisten ja materiaalisten tekijöiden yhteenkietoutumisena ja kehittyy pyrkimyksinä luoda sekä uutta tietämystä että käytäntöjä eri osaamisrajojen välisesti.
\end{abstract}

TUTKIMUKSET ASIANTUNTIJUUDESTA ovat keskittyneet pitkälti siihen, kuinka ihminen selviytyy työssään ja oppii tai ratkaisee ongelmia yksilöllisesti ja tietyn osaamisalueen sisällä. Kattavan kuvan uranuurtavasta tutkimuskentästä saa Ericssonin työn kautta (2009; Ericsson ym 2006). Tarkastelukulma on ollut luonteva, koska useimmilla työn alueilla taitavaan suoriutumiseen ei ole tarvinnut ylittää asiantuntijuusrajoja. Monessa ammatissa tilanne on kuitenkin viime vuosina muuttunut ratkaisevasti. Organisaatioiden toiminta perustuu yhä enemmän asiantuntijuusalueiden sulautumiseen, jopa organisaatioiden välisesti, koska tuotteet ja palvelut tulevat asiakkaiden vaatimuksesta monimuotoisemmiksi. Haluamme tutkimuksellamme seurata työn kehityssuuntaa, jossa tärkeäksi nousevat kollektiivisen asiantuntijuuden piirteet.

Tässä artikkelissa asiantuntijuutta tarkastellaan kolmesta näkökulmasta: yksilöllisenä tiedonhankintana, kulttuuriin osallistumisena ja yhteisöllisenä tiedonluomisena (Hakkarainen, Palonen, \& Lip- ponen 2003; Paavola, Lipponen, \& Hakkarainen 2004; Hakkarainen, Palonen, Paavola, \& Lehtinen 2004). Yhtenäisen kokonaiskuvan muodostaminen asiantuntijuudesta edellyttää käsityksemme mukaan kaikkien kolmen näkökulman huomioon ottamista. Raportoimalla alustavia tuloksia kahdesta allekirjoittaneiden toteuttamasta ammatillisen asiantuntijuuden tutkimushankkeesta, muotoilemme tässä artikkelissa kollektiivisen asiantuntijuuden näkökulmaa, jossa yhdistyvät asiantuntijuuden yksilölliset sekä yhteisölliset ja verkostoituneet ulottuvuudet, sosiaalisen ja materiaalisen yhteenkietoutuminen sekä pyrkimys uutta tietoa ja käytäntöjä luovaan toimintaan.

\section{ASIANTUNTIJUUS TIEDONHANKINTANA}

Tutkijat ovat eritelleet korkeamman tason pätevyyksiin liittyviä älyllisiä prosesseja 1970-luvulta lähtien. Nämä tutkimukset osoittavat, että vastoin tutkijoiden odotuksia asiantuntijoiden ja aloittelijoiden yleiset päättely- tai muistitaidot eivät poikkea toisistaan. Asiantuntijuuden tiedonhankintanäkökulma olettaa, 
että asiantuntijoiden poikkeuksellinen suoriutuminen perustuu laajaan, hyvin organisoituun ja käyttökelpoiseen, kristallisoituneeseen tietämykseen, joka auttaa ongelmanratkaisun olennaisten tekijöiden erottamisessa epäolennaisista (ks. Baltes, Staudinger, \& Lindenberg 1999; Bereiter \& Scardamalia 1993; Feltovich, Ford, \& Hoffman 1997). Asiantuntijat työskentelevät haastavien tavoitteiden saavuttamiseksi nojautumalla rajattuun joukkoon joustavaa tietämystä ja kehittävät uusia käytäntöjä ja toimintakaavioita uuden toiminnan muuntamiseksi rutiineiksi (kristallisoitunut tietämys). Näin he vapauttavat älyllisiä voimavarojaan toteuttaakseen vielä vaativampia projekteja. Toiminta muuttuu asteittain helpommaksi kristallisoituneen tietämyksen avulla, joka kantaa sisällään ratkaisumalleja ja rutiineja alun perin sotkuisten ja hankalien ongelmatilanteiden käsittelemiseksi. Adaptiiviset asiantuntijat ovat niitä, jotka jatkuvasti investoivat kokemuksen myötä vapautuvia resursseja uuden oppimiseen (Hatano \& Inagaki 1992). Tämän näkökulman pohjalta asiantuntijat nostavat osaamistasoa korkeammalle, koska he ovat yhden tai useamman vuosikymmenen ajan harjoittaneet ja omaksuneet rikasta ongelmanratkaisutietämystä. Tämä mahdollistaa mielekkään ja tehokkaan toiminnan tutuissa sekä harvoin esiintyvissä tilanteissa.

\section{ASIANTUNTIJUUS KULTTUURIIN OSALLISTUMISENA}

Edellä kuvattu psykologinen asiantuntijuuden tutkimus tarjoaa yksilökeskeisen ja mentalistisen kuvan asiantuntijuuden luonteesta. Osallistumisen näkökulmasta asiantuntijuuden kehitys sisältää puolestaan ajatuksen, kuinka aloittelijan rooli ja osallistuminen aluksi osaamisyhteisön (engl. Community of practice) reunalla muuntuu tärkeäksi kollektiivisten käytäntöjen omaksumisen kautta (Lave \& Wenger 1991). Asiantuntijoiden kristallisoitunut tietämys ei synny heidän mielensä syvyydestä, vaan se omaksutaan ja sisäistetään kulttuurihistoriallisesti kehittyneistä asiantuntijakulttuureista niihin osallistumisen kautta. Asiantuntijuus kehittyy sosiaalisiin yhteisöihin kasvamisena ja niiden toimintaan osallistumisena, jossa tapahtuu arvojen, normien ja käytäntöjen sisäistäminen. Asiantuntijuutta ei voida ymmärtää yksilön mentaali- seksi prosessiksi, koska se on monimutkaisten tietoartefaktien sekä osaamisryhmien sosiomateriaalisesti välittämää ja esiintyy kollektiivisissa tietämysverkoissa (Hutchins 1995). Kaiken kaikkiaan asiantuntijuutta on paljon tutkittu yksilöllisenä ongelmanratkaisun kapasiteettina, mutta kulttuurihistoriallisesti välittyneisiin ja sosiaalisesti hajautuneisiin asiantuntijuuden ulottuvuuksiin ei ole kiinnitetty riittävästi huomiota.

\section{ASIANTUNTIJUUS TIEDONLUOMISENA}

Ihmiset työskentelevät yhä useammin moniammatillisissa tiimeissä, joissa pelkkä oman alan asiantuntijuuden vertikaalinen kehittäminen ei ole riittävää; pikemminkin ihmisten täytyy osallistua horisontaaliseen oppimiseen, eli oman osaamisen suhteuttamiseen ja sulauttamiseen muiden tiiminjäsenten osaamiseen (Engeström, Engeström, \& Kärkkäinen 1995). Paavola ja hänen työtoverinsa (2004; Hakkarainen ym. 2003) ovatkin esittäneet, että kehittyneelle tietoyhteiskunnalle tyypillisen asiantuntijuuden ymmärtäminen edellyttää tiedonluomisen ja sosiaalisten käytäntöjen muuttamisen näkökulmaa. Tiedonluomisen näkökulmasta asiantuntijuuteen ei ensisijaisesti liity olemassa olevan tiedon hankkiminen tai vakaaseen kulttuuriin kasvaminen, vaan tietoinen pyrkimys vallitsevan tietämyksen ja tietokäytäntöjen tarkoitukselliseen muuttamiseen. Kollektiivinen asiantuntijuus tuntuu olevan jonkun jaetun yhteisen kohteen kehittämiseen suuntautunut "kohteellinen" prosessi. Nämä kohteet voivat olla ideoita, teorioita, suunnitelmia, konkreettisia tuotteita tai reflektion kohteena olevia käytäntöjä. Kollektiivinen asiantuntijuus näyttää kehittyvän yhdessä pitkäaikaisen ja tarkoituksellisen kohteiden kehittämisen prosessin kanssa (Paavola ym. 2004). Tietointensiivistä työtä tehdään nopeasti muuttuvassa ja myrskyisässä toisen asteen ympäristössä (Bereiter \& Scardamalia 1993), jossa onnistuneen suorituksen kriteerit muuttuvat asteittain tiukemmiksi muiden toimijoiden onnistumisen seurauksena. Tällaiset ympäristöt edellyttävät, että asiantuntijayhteisöt osallistuvat jatkuvaan innovaatioiden ja sosiaalisten käytäntöjen muuttamisen prosessiin vastatakseen kaikille osanottajille uusiin haasteisiin. Knorr Cetina (2001, 178) esittää, että perinteinen toistuviin rutiineihin, totuttuihin 
toimintakaavioihin ja jäykkiin sääntöihin nojautuva käytännön käsite ei vastaa episteemisten yhteisöjen tilannetta, joiden täytyy antautua uudenluomista ja innovaatioita palvelevaan jatkuvaan, tarkoitukselliseen ja järjestelmälliseen tietokäytäntöjen uudelleen keksimiseen. Tämän pohjalta esitämme, että ajallemme tyypillisen luovan kollektiivisen asiantuntijuuden voidaan olettaa jalostuvan innovatiivisissa tietoyhteisöissä pikemmin kuin perinteisissä käytäntöyhteisöissä (Hakkarainen ym. 2003; 2004). Kuitenkin nämä yhteisöt nojautuvat sosiaalisiin käytäntöihin, tietokäytäntöihin, jotka on räätälöity tukemaan jatkuvaa innovaatiota ja muutosta. Analogisesti kristallisoituneen ja joustavan tietämyksen näkökulmien kanssa tiedonluomisen käytännöt sallivat yhteisöjen ponnistella ongelman ratkaisemiseksi ja muuntaa siihen liittyviä prosesseja rutiineiksi saadakseen uusia voimavaroja oman suorituskyvyn ylärajoilla ponnisteluun. Tietointensiivisen työn asiantuntijat eivät ainoastaan työskentele aikaisempaa oleellisesti monimutkaisempien kohteiden kanssa. Nämä kohteet eivät ole ennalta määräytyneitä, vaan luonteeltaan joustavia ja liukkaita niin, että niitä jatkuvasti muunnellaan ja määritellään uudelleen toiminnan kuluessa (Knorr Cetina 2001; Miettinen \& Virkkunen 2005).

Seuraavassa raportoimme tuloksia kahdesta kollektiivisen asiantuntijuuden tutkimushankkeesta, jotka liittyvät monimutkaisiin työympäristöihin. Tapaukset sisältävät sekä kulttuuriin osallistumiseen että tiedonluomiseen liittyviä ulottuvuuksia. Ensimmäinen tutkimus käsittelee välittävien artefaktien ja teknologian tukemien tietokäytäntöjen roolia insinöörisuunnittelussa. Toinen käsittelee uuden teknologian yrityksessä esiintynyttä risteytynyttä asiantuntijuutta sosiaalisesti hajautuneena ja relationaalisena prosessina, eli oman toiminnan suhteuttamista suhteessa toisiin toimijoihin, käytettyihin välineisiin, erilaisiin tavoitteisiin, toimintakonteksteihin ja työkäytäntöihin.

\section{TUTKIMUS 1. TIETOARTEFAKTIEN ROOLI INSINÖÖRISUUNNITTELUSSA}

\section{Tutkimusongelma}

Tutkimuskohteena oli uuteen tieto- ja viestintätekniikkaan (TVT) perustuvien digitaalisten välinei- den rooli viidessä mekaanista insinöörisuunnittelua tekevässä keskisuuressa (250-700 työntekijää) ja pääasiassa kansainvälisillä markkinoilla toimivassa yrityksessä (Björkstrand \& Lallimo 2006). Tutkimuksessa kartoitettiin uusia digitaalisia suunnittelukäytäntöjä ja niihin liittyviä haasteita suhteessa tietoartefaktien luomiseen, käyttämiseen ja uudelleen käyttämiseen. Tietoartefaktilla tarkoitetaan ammattilaisen tietämyksen kiteyttämistä ja ulkoistamista jaetuksi kohteeksi, jonka kanssa työyhteisön jäsenet voivat olla vuorovaikutuksessa, jota voidaan kommentoida, edelleen kehittää ja käyttää uusien kohteiden luomisen perustana. Tietoartefaktit voivat esiintyä eri muodoissa, kuten paperilla esitetty graafinen piirustus tai 2- tai 3-ulotteinen digitaalinen malli, joiden välityksellä voidaan luoda prototyyppejä ja konkreettisia tuotteita. Yritykset valmistivat hyvin erilaisia tuotteita, kuten esimerkiksi erikoistuneita sähköisiä valaistusjärjestelmiä, teollisuushissejä, sotilaallisia maastoajoneuvoja ja vuolukiviuuneja. Ne olivat käymässä läpi siirtymää tietokoneavusteisesta 2D-suunnittelusta 3D-suunnitteluun ja siihen liittyvään suunnitteludokumenttien uudelleen käyttöön ja muokkaamiseen. Käytettävät 3D-välineet oli integroitu älykkääseen tuotetiedon hallintajärjestelmään (engl. Product Data Management system, PDM) joka uudella tavalla sulauttaa tuotesuunnittelua ja valmistusta yhteen. Tutkimuksen tavoitteena oli eritellä (a) millaisia tietoartefakteja insinöörit luovat ja millaisia työvälineitä ja tietoa käytetään niiden luomisessa ja (b) kuinka henkilökohtainen ja kollektiivinen asiantuntijuus liittyvät suunnitteluartefaktien tuottamiseen, käyttöön ja uudelleen käyttöön suunnitteluprosessin aikana?

\section{Menetelmä}

Tutkimusaineisto hankittiin toteuttamalla yrityksissä yhteensä 31 puolistrukturoitua haastattelua tutkijoiden kussakin yrityksessä organisoiman kollektiiviseen asiantuntijuuteen liittyvän työpajan yhteydessä. Haastateltavat valittiin siten, että he edustivat erilaisia toimintoja tuotesuunnittelusta myyntiin ja tuotantoon; noin puolet oli suunnittelijoita ja toinen puoli edusti projektipäälliköitä, myyntihenkilökuntaa, tuotantoa ja tuotekehitystä. Haastatteluissa eri- 
teltiin haastateltavien ammatillista historiaa ja heidän kokemiaan suunnittelutyön historiallisia muutoksia, suunnittelutiedon hallintaan liittyvän sosiaalisen verkoston luonnetta (ihmisistä ja artefakteista muodostuvan henkilökohtaisen sosiaalisen verkoston kuvaaminen piirtämällä) ja tiedonhallinnan tallentamisen, käyttämisen ja luomisen teknologisia ja sosiaalisia ulottuvuuksia. Haastattelut olivat keskimäärin 74 minuutin mittaisia ja niitä muodostui noin 500 sivua tekstiksi purettua aineistoa. Laadullisen analyysin kohteena olivat erityisesti tietoartefaktien luominen, käyttö ja jakaminen sekä siinä käytettävät välineet.

Haastattelujen ja informanttien tuottamien verkostokuvien avulla rakennettiin kuva tiedonkulun ja dokumentoinnin muodoista ja toiminnasta yrityksen tuotekehityksessä. Lisäksi haastatteluista analysoitiin kollektiivisen asiantuntijuuden viitekehyksessä suunnitteludokumenttien tuottamisen ja käytön tietokäytäntöjä. Analyysiyksikkönä olivat työntekijän kuvaamat tietokäytännöt suunnittelutyössä tietyn dokumenttityypin kanssa.

\section{Tulokset}

Vastoin usein käytettyä lineaarista tuotekehityksen vesiputousmallia, jossa tieto käsitellään ja siirretään eteenpäin vaiheittain, työntekijöiden kuvaukset muistuttivat enemmän dynaamista verkostoa jossa erilaiset suunnittelukäytännöt ja prosessit toimivat yhtä aikaa. Tämä dynaaminen verkosto piti sisällään useita erilaisia asiantuntijakäytäntöjä, jotka olivat vuorovaikutuksessa tietojärjestelmien ja suunnitteluartefaktien välityksellä. Verkostot olivat alati muutoksessa, jossa yksi artefakti saattoi olla keskeinen tietyllä ajanhetkellä, joutua siirretyksi syrjään jonkin ajan kuluttua ja tulla taas myöhemmin uudelleen tärkeäksi kohteeksi suunnitteluprosessissa. Haastateltavien selostukset tietoartefaktien käytöstä olivat suurilta osin tiiviisti kytköksissä tiettyyn verkostoon, jossa ne oli tuotettu. Esimerkiksi tietyn suunnitteludokumentin mielekäs tulkitseminen edellytti tietoutta yhdestä tai useammasta seuraavista käytännöistä:

1. Yleiset asiantuntijakäytännöt (alaan liittyvät suunnitteluvälineet sekä suunnittelumerkistöt ja niiden tulkinta, esimerkiksi sähköpiirustukset, tuotantokuvat jne.).
2. Yrityksen käytännöt (esimerkiksi historiallisesti muodostuneet käytännöt yrityksen sisällä, kuten laatuvaatimukset, suunnittelutiedon dokumentoimisen käytännöt).

2. Tietoverkoston käytännöt (poikkeama yleisistä yrityksen käytännöistä erityisen, yrityksen ulkopuolisen tarpeen takia, esimerkiksi häiriö tietyn osan alihankkijan tuotannossa, maittain vaihtelevat turvallisuusmääräykset, asiakkaan erikoistoivomukset jne.)

Kaikissa tutkimuskohteissa suunnittelukäytäntöjen muuttamisen pääkohteena oli suunnitteludokumenttien tuottamisen ja uudelleenkäytön tehostaminen. Suurin osa yritysten myynnistä oli niin sanottua "massaräätälöintiä", jossa olemassa olevasta mallistosta räätälöitiin asiakkaan tarpeisiin sopiva tuote ja siihen liittyvä palvelu. Moderneissa insinöörityön tuotteissa saattaa olla kymmeniätuhansia osia, joita on vaikea hallita ilman kehittyneitä tietokoneavusteisen suunnittelun ympäristöjä. Uuden 3Dsuunnittelujärjestelmän käyttöönotto pakotti yritykset myös arvioimaan vanhoja toimintatapojaan. Missään viidestä yrityksestä ei ollut yksityiskohtaista laatukäsikirjaa, tapaa tehdä suunnittelutyötä, ja vanhojen suunnitelmien tietokanta olikin tärkein yhteinen viitekehys suunnittelijoiden välillä. Tietokannat oli kuitenkin järjestetty yleensä lopputuotteen ja projektikuvauksen mukaan (päiväys, asiakas, jne.), kun taas suunnittelijat useimmiten etsivät dokumentteja tietyn suunnitteluongelman mukaan. Löytääkseen etsimänsä he joutuivat luottamaan omaan muistiinsa tai etsimään käsiinsä toisen suunnittelijan, joka muisti vanhan projektin, jossa oli kohdattu sama ongelma. Monessa tapauksessa tarvittiin tietoutta hyvin erilaisista käytännöistä. Käytettyjen tietoartefaktien kirjo oli moninainen ulottuen käsinkirjoitetuista muistiinpanoista 3D-malleihin ja todellisiin prototyyppeihin. Suunnittelukäytännöt olivat moninaisia ja käytössä olivat rinnakkain perinteinen piirustuslauta, 2D- ja 3D-suunnitteluohjelmistot.

Seuraava ote havainnollistaa haastateltavan kuvausta erilaisista tavoista, joilla suunnittelijat liittyvät projektin verkostoon. Ennen kuin virallinen toimeksianto (yrityksen käytäntö) suunnittelijoille on tehty myyntiedustaja saattaa neuvotella dokumenttien 
yksityiskohdista suunnittelijan tai tuotantopäällikön kanssa. Tämä edellyttää, että myyjä tuntee suunnittelijan ja on tietoinen tämän verkostosta.

"Se on hyvin moninaiset tilanteet et joskus sieltä saattaa myyntipäällikkö soittaa jostakin tuolta asiakkaan luota että onko mahdollista tehdä tällanen ja tällanen ja mä sitten kerron oman näkemykseni että onko vai eikö. Joskushan ratkasee se että pystytäänkö osa tekemään meidän automaatiolinjalla kun se ehkä parhaiten tiedetään täällä tuotannon päässä sitten taas mitkä on suunnitteluresurssit ja niitten aikataulut ne tietää suunnittelupäälikkö. Ja riippuen sit tietysti henkilökohtaisista että minkälaiset välit on tunteeko ihmiset toisesta tietää osaamisalueet et esimerkiks niinku mitäs no meil on nyt uus myyntitykki et hän ei oo koskaan kysynyt kommentteja mult, sit taas [asiantuntijan nimi] soittelee hyvin avoimesti mikä on meidän myyntipäällikkö niin että kun siinä tietää ja tuntee." (Tuotantopäällikkö).

Myöhemmin haastateltava kuvailee, kuinka suunnitteludokumenttien ympärillä käytävään keskusteluun usein liittyy erilaista asiantuntijuutta, kuten suunnittelijan kyky tunnistaa aikaisempia suunnitelmia, joita voidaan käyttää hyväksi, tai kyky arvioida kuinka mahdolliset uudet muutokset vaikuttavat tuotantoprosessiin.

"... jos se [asiakas] tarvii nopeesti jonkun mallin tietää et on olemassa oleva tuote niin turha silloin on enää sellaseen ees suunnittelun voimavaroja tuhlata kun ensin tarjotaan joku meille olemassa oleva laite vähän modifioidaan sitä ja tarjotaan tuota pikalähetyksenä jollekin et nyt saa konkreettisesti pyöritellä käsissään. Täs on huomattu että se 3D kuva ei oo ihan vaan totta aina taikka käytännön totuus jostakin syystä että vaikka siel on kaikki luvut ja kaikki ohjelmat ja muut." (Insinööri).

Suunnitteluprosessin verkostossa tietoartefaktit saattoivat palvella monia tarkoituksia: suunnittelun kohteena, suunnittelua välittävänä artefaktina tai rajakohteena eri asiantuntijakäytäntöjen välillä. Kaikissa yrityksissä oltiin ottamassa käyttöön tuotetietojärjestelmää (PDM), joka yhdistää komponenttitiedot, tuotteiden hinnat ja suunnitteludokumentit. PDM toimi välittävänä työkaluna verkostossa osoittaen suunnittelijoille selvät reunaehdot esim. tuotannon aikataulutuksesta ja valmistuskustannuksista. Usein ratkaisu, jota suunnittelijat pitivät parhaana, saattoi osoittautui mahdottomaksi valmistaa aikataulun puitteissa tai sen kustannukset olivat huomattavasti vaihtoehtoa suuremmat. PDM-järjestelmä toimi myös rajakohteena, johon erilaista asiantuntijuutta edustavat haastateltavat viittasivat kuvauksissaan suunnitteluprosessista. Yhdessä yrityksistä PDMjärjestelmä oli hankittu vastauksena tiedonhaun ongelmaan, linkittämään arkistoidut projektidokumentit itse suunnitteluprosessin. Nuori 3D-CAD (Computer-aided Design) ja PDM-järjestelmiin erikoistunut insinööri oli palkattu yritykseen järjestelmien käyttöönottoa varten. Seuraavassa hän kuvailee syitä tiedon taltioimista säätelevän suunnittelustandardin käyttöönotosta yrityksessä, jotta

"löytyis se kaikki tieto periaatteessa siitä semmonen (...) tieto että mistä sinä voit sitä etsiä (...) se on tossa vanhassa järjestelmässä niin se on aika iso ongelma kyllä että ne on vaan siellä palvelimella on tietty kansio minkä alla on tiettyjä kansioita ja sitten ne ei niin kun periaatteessa ohjaa ollenkaan ne kansiot se on melkein tiedettävä et täähän on tänä vuonna on tai oiskohan se sinä vuonna tehty se [TUOTEMALLI] jos näitä malleja lähdetään etsimään mut tietysti PDM nyt tois sen jos sen sais niin hyvästi iskostettua ihmisten mieleen että ne nyt sitten laittais sinne PDMään sitä tavaraa." (Insinööri.)

Haasteena oli se, että monessa tapauksessa asiakasprojektin yhteydessä oli helpointa nojautua vanhan menetelmän mukaisesti tuotettuihin suunnitteludokumentteihin, koska materiaalia oli paljon. Vaikka uudella menetelmällä syntyi nopeasti visuaalisia tuotemalleja, se vei kuitenkin oman aikansa, koska ne oli luotava 3D-järjestelmässä uudelleen. Tämä vaati aikaa, jolloin 3D-mallien tuottaminen asiakastarjousten tueksi ei aina ollut mielekästä, koska vain osa tarjouksista johti myyntiin. Yksittäisten suunnittelijoiden käytännöissä yrityksen sisällä pystyttiin tunnistamaan useita eroavuuksia. Nuoret, juuri val- 
mistuneet suunnittelijat omasivat yleisesti paremmat taidot suunnitteluvälineiden, kuten 3D-CADin käytössä ja huomasivat useammin ristiriitaisuuksia yrityksen käytännöissä. Toisaalta, kauemmin yrityksessä työskennelleet kertoivat, että heillä oli kulunut useita vuosia ennen kuin he oppivat riittävän hyvin tuntemaan yrityksen sisäisen tietoverkoston, hahmottamaan muiden suunnittelijoiden käytäntöjä ja tyylistä tunnistamaan suunnitteludokumenttien tekijät esittääkseen tarvittavia lisäkysymyksiä.

Tutkituissa yrityksissä työtä kehitettiin suurilta osin kahdella eri tavalla. Ensinnäkin se perustui uusien suunnitteluvälineiden käyttöönottoon (kuten 3D-CAD ja PDM) tukemaan tiedonhallintaa suunnitteluprosesseissa. Toiseksi yrityksillä oli tuotekehitystiimejä, jotka työskentelivät tiiviisti yhteistyössä suunnittelijoiden kanssa. Nämä kehitystiimit olivat paikka, jossa uusia ideoita voitiin kehittää ja testata nopeassa syklissä. Tuotekehitystä kuvailtiin sekä ylhäältä-alas (top-down) että alhaalta-ylös (bottomup) eteneväksi prosessiksi. Projekteja käynnistettiin sekä johdon aloitteesta uuden mallin luomiseksi että tuotannon ja suunnittelun innovaatioiden perusteella. Tuotekehityspäällikkö kivituotteita valmistavassa yrityksessä kuvaili erästä uuteen ideaan perustunutta tapausta seuraavasti:

"Käytännössä mie piirtelin sit vähän aikaa AutoCADilla ja sitten siihen tuli yks toinen tuotannosta tuli kaveri joka on tuotannossa ollu kymmenen viistoista vuotta täallä niin se oli tavallaan tuotannon näkemystä siihen ja sitten hänen kanssa siinä kahestaan ideoitiin sitä hommaa ja sitten mentiin me mallimestarin tai niin kun prototyypin kasaajan luokse ja sitten hän ideoi lisää sitä hommaa. Sit meitä oli jo kolme siinä ja sitten ja sit siihen tuli vielä yks suunnittelija sitten siihen mukaan kattomaan että tää menis toi tonne ja ... ja sitten seuraavana päivänä pistettiin kasaan ja sit meit oli koko porukka kattomassa että mitenkäs tää olis mahdollista tehdä ja sit siinä oli ukkoa sen lavan ympärillä niin paljon kun siihen mahtuu suurin piirtein ja jokainen heitti kommenttia siihen."

Edellinen esimerkki kuvaa, kuinka idea uudesta tuotantomenetelmästä muotoutui 3D-CADilla tuote- tuksi suunnittelupiirrokseksi ja edelleen todelliseksi prototyypiksi, jonka kehittämisessä tarvittiin moninaista asiantuntijuutta. Usein heidän täytyy työskennellä monien eri tietoedustusten kanssa (paperilla olevat suunnitelmat ja suunnitelmat, joita on tuotettu eri sukupolvia edustavien tietokoneavusteisen suunnittelun [engl. Computer-aided Design, CAD] ympäristöjen avulla) niin, että olennaisten piirustusten löytäminen ja uusimpien versioiden tunnistaminen saattaa olla työlästä.

Tutkimuksen tulokset osoittavat, että asiantuntijuutta suunnitteluprojekteissa ei voida täysin erottaa historiallisesti muotoutuneesta yrityksen käytäntöjen kehityksestä tai tietoverkostojen kehityksestä. Yrityksissä suunnittelun ja tuotekehityksen tietokäytännöt olivat jatkuvassa muutoksessa, ja lähes poikkeuksetta tuotettujen suunnitteludokumenttien tulkitseminen vaati näiden tietokäytäntöjen tuntemista. Lisäksi yhteisen kohteen muodostamista eri käytäntöjen välillä välitti usein teknologinen suunnittelujärjestelmä, joka mahdollisti monien erilaisten representaatioiden muodostamisen muotoutuvasta yhteisestä kohteesta.

\section{TUTKIMUS 2. HENKILÖKOHTAISEN JA KOLLEKTIIVISEN ASIANTUNTIJUUDEN YHDISTYMINEN SUUNNITTELU- INTENSIIVISESSÄ TYÖSSÄ}

\section{Tutkimusongelmat}

Toinen tutkimus käsitteli yhteisöllisiä tietämysverkostoja yrityksessä, joka kehittää internetpohjaisia työ- ja yhteisösovelluksia kotimaisille ja ulkomaisille markkinoille. Kohdeyritys oli kohdannut ongelmia omiksi saarekkeikseen eriytyneiden tuotekeskeisen teknisen tietämyksen ja asiakaskeskeisen tietämyksen yhdistämisessä. Tutkijat kutsuttiin yritykseen tilanteessa, jossa yritys oli käynnistänyt projektin tiedon jakamisen käytäntöjen ja uusien tuotteiden kehittämiseksi. Haasteena oli, kuinka vertikaalista, syvää asiantuntijaosaamista edustava ja organisaatiossa usein hajallaan oleva tieto saadaan yhdistymään monialaisesti ja edelleen kehittymään. Tutkimus kohdistui yrityksen kommunikaatiorakenteisiin ja käytäntöihin, jotka edustivat olemassa olevan tiedon 
(kristallisoitunut tieto) jakamisen ja uuden tuotetietämyksen (juoksevan tiedon) tuottamisen rakenteita. Tutkijat olivat erityisen kiinnostuneita tiedonjakamista tukevista verkostorakenteista ja tiedon välittämisen (Burt 1992) käytännöistä. Raportoimme tässä tutkimuksen siitä osiosta, joka kohdistui niihin työntekijöihin, jotka välittivät tietoa ja kokemuksia toimimalla tiedonvälittäjinä ja portinaukaisijoina organisaation osaamisrajojen välillä. Tiedonvälittäjät ovat toimijoita, jotka pystyvät yhdistelemään olemassa olevia resursseja uusilla tavoilla nojautumalla risteytyneeseen (eli hybridiin, Howells 1998) asiantuntijuuteen. Tällaisen osaamisen varassa yhden asiantuntijakulttuurin kieli ja tietämys voidaan 'kääntää' ja muokata toiselle kulttuurille ymmärrettäväksi (Sverrisson 2001). Esimerkiksi informaatioteknologian alueella toimijan hybridi asiantuntijuus tulee esille teknisen kyvykkyyden, asiakas- ja myyntitietämyksen yhdistämisenä ja näiden rajapinnassa tapahtuvana uuden oppimisena ja kehittämisenä. Tutkimuksen pääkysymys kohdistui siihen, kuinka tiedonvälittäjät toimivat ja millaista heidän osaaminen on moniammatillisessa verkostossa. Tutkimuksen tavoitteena oli eritellä sekä tiedonvälittäjien asemaa kommunikaatioverkostossa että heidän asiantuntijuutensa ja työkäytäntöjensä eri ulottuvuuksia. Vaikka tutkimuksen kohteet olivatkin yksilöitä, tavoitteena oli tietämys kollektiivisen verkoston sidoskohdista.

\section{Menetelmät}

Tutkimuksen kohteena oleva yritys tuottaa internetpohjaisia yhteistyösovelluksia yritykseltä yritykselle sekä yksityiselle että julkiselle sektorille. Sen palveluksessa oli tutkimushetkellä noin 1000 työtekijää myyntitoimistoissa, tekniseen kehitykseen keskittyneissä keskuksissa sekä partneriyrityksissä eri maissa. Tämä tutkimus kohdistui erityisesti yksikköön, jossa oli 119 työtekijää, jotka edustivat kokonaisvaltaista toimintaa kehityksestä myyntiin. Tutkimus oli osa kolmen vuoden tutkimuskokonaisuutta, joka kohdistui moniammatillisen ja hajautuneen tietämyksen hallintaan.

Tutkimusaineisto hankittiin nojautumalla kahteen menetelmään. Sosiaaliseen verkostoanalyysiin pohjautuvan kyselyn (Wasserman \& Faust 1994) avulla jokainen työntekijä arvioi kommunikaatiosuhteensa jokaiseen muuhun työtekijään. Heiltä kysyttiin (a) keneltä he saavat tietoa yrityksen eri tuotteista tai asiakkaista ja (b) kenen puoleen he kääntyvät kysyäkseen neuvoa. Kaikki työntekijät täyttivät lomakkeen, joka koodattiin ja analysoitiin UCINET-ohjelmalla (Borgatti, Everett, \& Freeman 2002, UCINET versio 6.182). Käyttämällä hyväksi verkostoanalyysin tarjoamaa tietoa yrityksen kommunikaatiorakenteista nostimme esiin 10 tiedonvälittäjinä toimivaa työntekijää. Lähtökohtana oli niin sanottu betweennes-arvo, joka ilmentää sitä, kuinka usein toimija on kommunikaatioverkostossa kahden muun sellaisen toimijan välissä, jotka eivät muuten ole suorassa yhteydessä toisiinsa. Verkostoanalyysin varassa tunnistetut tiedonvälittäjät haastateltiin puolistrukturoidulla teemahaastattelulla, jonka kohteena olivat heidän asiantuntijuusalueensa, työkokemuksensa sekä tiedonvälittämisen ja tiedonkehittämisen työkäytännöt. Noin 100 minuutin haastattelut purettiin nauhoilta tekstimuotoon. Laadullisen analyysin pohjana olivat sekä olemassa olevat teoriat tiedonvälittämisestä osana kollektiivisia työkäytäntöjä että aineistolähtöinen lähestymistapa. Kokonaisuus ja analyysiluokat hahmottuivat useiden analyysikierrosten tuloksena. Ensin kaikki tiedonvälittämistä koskevat lausumat nostettiin esille. Toiseksi lausumien pohjalta muodostettiin luokkia, joihin lausumat sijoitettiin ja joiden sisällä lausumia tarkasteltiin. Luokiksi muodostuivat (a) asiantuntijatiedon ja käytäntöjen välittäminen ylitse osaamisrajojen, (b) sosiaalisten verkostojen tunnistaminen ja edelleen tarjoaminen organisaation käyttöön, (c) tiedonvälittäjien toiminta organisaation oppimisen näkökulmasta sekä (d) ongelmat, jotka liittyvät tiedonvälittäjien toimintaan. Tulosten tulkinnassa auttoi se, että verkostoanalyysi- ja haastatteluaineiston lisäksi tutkijat hahmottivat yrityksen toimintaa osallistumalla ja dokumentoimalla kymmeniä kokouksia, työpajoja sekä muita epävirallisia työtilanteita.

\section{Tulokset}

Tulokset osoittavat, kuinka tietyt ihmiset toimivat välittäjinä monialaisten verkostojen rajapinnoilla. Verkostoanalyysi osoitti tärkeimpien tiedonvälittä- 
jien viestintäverkon olevan erityisen tiivis; se sisälsi keskimääräistä enemmän sekä työntekijöiden välisiä että yrityksen osaamisalueita ylittäviä verkostoyhteyksiä. Sijoittuminen muita toimijoita yhdistäville poluille (toimijaparien välillä olevat verkoston lyhimmät polut) mahdollisti sen, että tiedonvälittäjät kuulivat varhaisessa vaiheessa useista erilaisista lähteistä tulevasta uudesta merkityksellisestä tiedosta ja välittivät sitä yrityksen eri toiminta-alueiden välillä. Haastatteluissa tuli esiin, että tiedonvälitys ei ole yleinen kyky, vaan on suhteessa tiettyyn erityisosaamiseen tai tilanteeseen. Aineiston tarkastelussa nousi erityisesti esille risteytyneen asiantuntijuuden rakenne ja merkitys irrallisten osaamisalueiden yhdistämisessä, tietämyksen relationaalinen suhteuttaminen yrityksen toiminnan mahdollisuuksiin ja riskeihin sekä transaktiivinen tietämys (Moreland 1999) yrityksen resurssien paikasta ja saavutettavuudesta (tietämys siitä, mitä muut tietävät ja kuinka tämä on käytettävissä). Tiedonvälittäjien toiminta kohdistui yhtäältä virallisen organisaatioaseman mukaiseen työhön muun muassa myynti-, tuotekehityksen tai asiakastuen johtajina. Toisaalta he koordinoivat moniammatillisen työn vaatimia rajapintoja, joissa työn kieltä, työtapoja tai työn kohteita tehtiin näkyviksi muille osaamisalueille. Tällaiset tilanteet olivat tyypillisesti yhteisöllisiä ongelmanratkaisutilanteita, jotka nousivat esille ennakoimattomasti ja joihin ei ollut olemassa valmista kristallisoitunutta ratkaisua.

Risteytyneen asiantuntijuuden kehittyminen oli vaatinut tiedonvälittäjiltä monivuotista kehitysponnistelua eri osaamisalueilla ja niiden välillä. Näin omaa tiedonvälitystoimintaansa kuvasi käyttäytymistieteellisen koulutuksen ja pitkän käytettävyyskokemuksen omaava, tekniseen tuotekehitystyöhön koulutettu tuotepäällikkö.

"Nykyinen työnkuvani on monimuotoinen (...) Se koostuu asiakkaalta tulevien tuotevaatimusten hallinnasta suhteessa olemassa oleviin ja uusiin toiminnallisuuksiin ja tuotekehitysprosessin koordinointi yrityksen ja asiakkaan välillä. (...) osallistun markkinoinnin ihmisten kanssa erityyppisten myyntipresentaatioiden tekemiseen ... vastaan asiakkailta ja partnereilta ja omilta myyjiltä tuleviin tuotteita koskeviin kysymyksiin. Jos en itse tiedä niin kysyn sen kehityksestä ja sitten vastaan takasin ja toisaalta taas jos kehitys tarvitsee jotain tietoa myynnistä tai asiakasrajapinnasta niin mä sit taas käyn sieltä päästä kysymässä ja toimitan sitä myyntiin."

Nishiguchin (2001) erottelu toiminnallisten ja relationaalisten taitojen välillä on hyödyllinen tiedonvälittäjyyden tarkastelussa. Tiedon soveltamiseen liittyvien toiminnallisten valmiuksien lisäksi tiedonvälittäjältä vaaditaan relationaalista tietämystä, johon liittyy kyky yhdistää ja järjestää uudelleen omia ja muiden toiminnallisia taitoja yrityksen kokonaistilanteen hahmottamiseen perustuvalla tavalla. Kokonaisnäkökulman hallinnan merkitys tuli hyvin esille myyntipäälliköltä, jolla oli kahdenkymmenen vuoden työkokemus yrityksen teknisissä ja myyntitehtävissä:

"Mulla on tiettyjä asioita tämmösiä ohjaukseen liittyviä tehtäviä, esimerkiks se että kun on tää koko organisaation strategiamuutos käynnissä niin pitäis myynnin puolella pitää huoli että suuntautuu tänne paikallishallinnon suuntaan ja toimia ohjaavasti niin että työ vastaa tätä valittua strategiaa mieluummin kuin että mentäis aina sen sillä tietyllä hetkellä houkuttelevimman vaihtoehdon suuntaan."

Yritykselle, jonka toiminta pohjautuu eri alojen asiantuntijuuden yhteensovittamiseen ja yhteiseen kehittymiseen, on elintärkeää tietää, mistä yrityksen osasta tai keneltä tieto ja osaaminen löytyvät. Tämä nousi haastatteluissa esille transaktiivisena tietona (Moreland 1999) siitä 'kuka tietää mitäkin', minkä merkitystä korosti eräs kehityspäällikkö:

"Ihmiset tulevat kysymään minulta vanhoista ratkaisuista ja kuka ne on tehnyt aikaisemmissa projekteissa (...) Mun työlle on tärkeetä tietää ja varmistaa, missä sitä tietoa on, koska mun päässä se ei millään pysy. Mulle on hyvin tärkeetä se, että ihmiset tietää, missä tietoa on ja että ihmisillä on tarvitsemansa tieto."

Organisaation transaktiivisessa tiedossa olennaista oli vastavuoroisuus sen suhteen, että välittäjällä on tietoa siitä mitä muut tietävät, toisaalta myös muut tietävät että juuri tällä ihmisellä on tietoa muiden ihmisten tiedoista. 
Keskeisimmät tiedonvälittäjät näyttivät myös muodostavan oman sisäisen verkostonsa, ylätason välittäjäverkoston, joka tuki kokonaisnäkemyksen muodostamista yrityksen eri toiminta-alueista. Tehokkaan vuorovaikutuksen tukemisen lisäksi tiedonvälittäjillä näyttää olevan merkittävä rooli uusien kehitysnäkymien avaamisessa sekä uuden, risteytyneen tiedon luomisessa. Tiedonvälittäjät olivat yleensä keskitason johtajia, joilla on jo organisaatiokaavion mukaisesti yhteyksiä muihin osaamisalueisiin. Tosin, koska tutkittavassa organisaatiossa oli runsaasti muitakin vastaavissa asemissa olevia johtavia asiantuntijoita ilman vastaavaa tietämystä välittävää verkostoroolia, tiedonvälittäjien asemaa ei voida selittää pelkästään hierarkkisella johtajuusasemalla. Tiedonvälittäjyys näyttikin yhdistävän sekä organisaation virallista hierarkkista rakennetta että epävirallisia horisontaalisia suhteita, jotka perustuivat enemmän henkilökohtaisiin suhteisiin kuin virallisiin sopimuksiin tai asemaan. Haastatteluissa ilmeni, että vaikka tiedonvälittäjät tukevat sujuvaa osaamisen jakamista ja luomista, he olivat myös toisaalta tiedon pullonkauloja ja riippuen henkilökohtaisesta tilanteesta, osaamisesta sekä tavoitteista, värittivät tai suodattivat tietoa. Lisäksi organisaatio on haavoittuvainen, mikäli tiedonvälittäminen keskittyy harvoille ihmisille.

Tärkeä merkitys tiedonvälittämisessä oli erilaisilla tietoartefakteilla, kuten tieto- ja viestintätekniikalla ja erilaisilla dokumenteilla ja manuaaleilla. Ongelmatilanteissa tiedonvälittäjät paitsi konsultoivat muita ihmisiä myös käyttävät hyväkseen erilaisia projektiraportteja, laatukäsikirjoja, asiakastietokantoja ja teknisiä kuvauksia. Tiedonvälittäjät viittasivat erilaisiin artefakteihin osaamisensa ja toimintansa olennaisena tukena. Yhteisen tuotekehityksen ja uusien työkäytäntöjen luomisen tukena toimivat erilaiset muistiot ('white papers'), joiden varassa lupaavia uusia teknisiä ideoita jaettiin muiden organisaation toiminta-alojen kanssa. Parhaimmillaan tällaiset yhteisesti työstettävät tietoartefaktit toimivat "rajakohteina" (Star 1989), jotka mahdollistivat eri osaamisalueiden välisen neuvottelun työn ongelmakohdista, tavoitteista, ja kehittämiskohteista. Kaiken kaikkiaan ihmiset ja erilaiset artefaktit muodostavat toisiinsa kietou- tuneen järjestelmän tässä monialaiseen osaamiseen nojautuvassa organisaatioissa.

\section{TARKASTELU}

Samaan aikaan kun psykologinen asiantuntijuuden tutkimus auttaa hahmottamaan ihmisen pätevyyden perustekijöitä, se on vasta hiljattain siirtynyt tutkimaan kollektiivisissa tietämysverkostoissa esiintyvää tosielämän asiantuntijuutta. Käsittelemämme tapaustutkimukset osoittavat, että on epätyydyttävää kuvata osanottajien asiantuntijuutta pelkästään yksilöllisesti, koska ammatilliset pätevyydet määritellään relationaalisesti ja ne sisältävät risteävää osaamista sisäisten (tutkimus \& kehitys, suunnittelu, markkinointi, valmistus) ja ulkoisten (asiakkaat, alihankkijat) rajojen ylittämisenä. Tutkimukset osoittivat moninaisia tapoja, joiden välityksellä asiantuntijuutta jaetaan osanottajien välillä ja jalostetaan työyhteisöjen jaetuissa käytännöissä, joissa henkilökohtaiset, sosiaaliset ja materiaaliset tekijät yhdistyvät.

Asiantuntijuuden ymmärtäminen henkilökohtaisten taitojen kehittymisen ja henkilökohtaisen tiedonhankinnan näkökulmasta niveltyy osallistumisen ja tiedonluomisen näkökulmiin. Esimerkiksi, tiedonvälittäjillä oli kaikilla pitkä henkilökohtainen työkokemus usealta osaamisalueelta, kuten teknisen tietämyksen yhdistyminen myyntitietämykseen. Tämä risteytynyt, hybridi asiantuntijuus tuli yhteisön käyttöön siten, että tiedonvälittäjät kasvattivat uusia yhteisön jäseniä organisaation olemassa oleviin käytäntöihin sekä osaamisyhteisön ajatusten mukaisesti opastivat organisaation olemassa olevaan tietämykseen. Lisäksi, tiedonvälittäjien ja organisaation välinen liitto suhteessa organisaation oppimiseen ja tiedonluomiseen oli molemminpuolinen; tiedonvälittäjät pääsivät keskeisen verkostoasemansa avulla käsiksi organisaatiossa liikkuviin tiedon ituihin, joka toisaalta mahdollisti heidän henkilökohtaisen asiantuntijuuden kehittymisen ja toisaalta palautui organisaation käyttöön jalostuneina ideoina ja ratkaisuina. Samoin, tiedonvälittäjät yhdistivät eri tahoja yhteiseen ongelmaratkaisuun.

Asiantuntijuus tiedonluomisen näkökulmasta konkretisoituu tuloksiin, jotka osoittivat työn teknisen ja sosiaalisen organisaation olleen jatkuvan muu- 
toksen kohteena tutkituissa työyhteisöissä. Tämä pakotti työntekijät kamppailemaan jatkuvan epävakauden, koordinaation puutteen ja toiminnan katkosten kanssa. Tutkimuksen asiantuntijayhteisöt olivat jalostaneet erityisiä tietokäytäntöjä, joiden avulla käsiteltiin järjestelmällisesti esimerkiksi massatuotannosta massaräätälöintiin siirtymisen yhteydessä syntyneitä uusia ja ennakoimattomia ongelmia. Monet tutkituista organisaatioista olivat luoneet erityisiä tuotekehityslaboratorioita, joissa valitut asiantuntijat saattoivat päätoimisesti keskittyä innovaatioiden luomiseen ja uuden tutkimiseen. Heistä monet, tosin eivät kaikki, olivat kokeneita ja tuotannosta nousseita. Nämä asiantuntijat toimivat tietokäytäntövälittäjinä, jotka auttoivat yhteisöjä toteuttamaan rinnakkaisesti rutiininomaisia ja uutta luovia käytäntöjä. Kaikki asiantuntijayhteisöt työskentelivät joustavien ja muuttuvien kohteiden kanssa (Law \& Singleton, 2005; Engeström 2005), jotka olivat jatkuvan uudelleen määrittelyn ja tulemisen prosessissa pikemminkin kuin tuottamassa perinteisiä hyvin määriteltyjä ja vakiintuneita tuotteita. Nojautumalla samanaikaisesti esipakattuihin ja standardiratkaisuihin yhteisöt kehittivät korkeasti räätälöityjä tai täysin uusia tuotteita ja innovatiivisia palveluja. Sekä yhteisön uusilla että kokeneilla jäsenillä oli tärkeä rooli ratkaisujen luomisessa. Tämä tulos asettaa kyseenalaiseksi asiantuntijuuden kehittymisen tarkastelun osaamisyhteisöjen (Lave \& Wenger 1991) teoreettisesta näkökulmasta, jossa uudet jäsenet vähitellen kasvavat kohti yhteisön keskeisiä tietoja ja taitoja, jotka vain kokeneet jäsenet hallitsevat.

Toinen näkökulma asiantuntijuuteen tiedonluomisena oli tutkimuksen merkittävä havainto tietokäytäntöjen heterogeenisyydestä sekä organisaatioiden sisällä että niiden välillä. Perinne ja innovaatio, saavutetun hyödyntäminen ja uuden tutkiminen esiintyivät pitkiä aikoja yhdessä. Samaan aikaan, kun jotkut asiantuntijat sukelsivat 3D-suunnittelun ympäristöihin, muut vielä nojautuivat perinteiseen insinöörisuunnitteluun ja yhdistelivät piirustuspöytää tietokoneavusteisen 2D-suunnittelun tarjoamiin tietokäytäntöihin. Kaikissa yhteisöissä tarvittiin ihmisiä, jotka kantoivat kollektiivisen toiminnan historiaa ja loivat jatkuvuutta menneen, nykyisen ja tulevan toi-

minnan välille. Kollektiivisen asiantuntijuuden sosiaalinen ja materiaalinen piirre tulee esille siinä, kun insinöörit työskentelivät ja neuvottelivat kasvokkain ja samanaikaisesti merkittävä osa heidän työstään kohdistuu erilaisiin tietoartefakteihin, kuten piirustuksiin, suunnitelmiin, ja muihin dokumentteihin. Nämä artefaktit esiintyvät monessa muodossa graafisesti, tekstuaalisesti ja matemaattisesti alkaen suunnitelmista ja jatkuen prototyyppeihin ja valmiisiin tuotteisiin. Organisaation kollektiivisen älykkyyden materiaalisuus korostuu erityisesti silloin, kun työntekijät vaihtuvat, mutta tietoartefaktit kantavat tietämystä uusille työntekijöille. Teknologiat, tekstit ja fysikaalinen ympäristö näyttävätkin ankkuroivan tietoa ja toimivan vuorovaikutuksen infrastruktuurina ihmisten ja artefaktien välillä (vrt. Latour 1999). Asiantuntijatyö näyttää siten olevan valautunut monimutkaiseen historiallisesti kehittyneiden tietämyksen, työvälineiden ja käytäntöjen verkkoon, jota tilanteisiin sidottu sosiaalinen vuorovaikutus ja toiminnan vaihtuvat kohteet määrittävät.
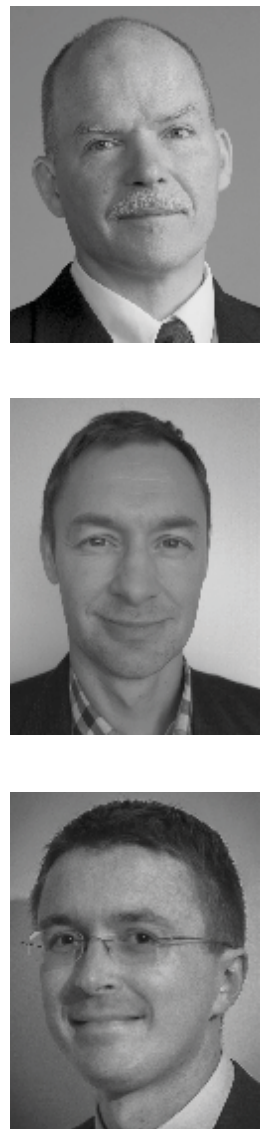

Kai Hakkarainen

professori

Turun yliopisto,

kasvatustieteiden laitos

Jiri Lallimo

tutkija

Toiminnan, kehityksen ja oppimisen tutkimusyksikkö, CRADLE

Helsingin yliopisto,

käyttäytymistieteiden laitos

Seppo Toikka

FM

Toiminnan, kehityksen ja oppimisen tutkimusyksikkö, CRADLE

Helsingin yliopisto, käyttäytymistieteiden laitos 


\section{LÄHTEET}

Bereiter, C. \& Scardamalia, M. (1993). Surpassing ourselves. Chicago: Open Court.

Björkstrand, R. \& Lallimo, J. (2006). Knowledge intensive design system - an attempt for better engineering environment. Teoksessa J. Malmqvist $\&$ F. Berglung (toim.), Proceedings of $1^{\text {st }}$ Nordic Conference on Product Lifecycle Management NordPLM'06, 243-253.

Burt, R. S. (1992) Structural holes. Harvard: Harvard University Press.

Clark, A. (2003). Natural-born cyborgs. Oxford: Oxford University Press.

Donald, M. (1991). Origins of the modern mind. Cambridge, MA: Harvard University Press.

Engeström, Y. (1987). Learning by expanding. Helsinki: Orienta-Konsultit.

Engeström, Y., Engeström, R., \& Kärkkäinen, H. (1995). Polycontextuality and boundary crossing in expert cognition. Learning and Instruction 5 (4), 319-336.

Ericsson, K. A. (2009). Development of professional expertise. Toward measurement of expert performance and design of optimal learning environment. New York: Cambridge University Press.

Ericsson. K.A. Charness, N., Hoffman, R.R.\& Feltovich, P.J. (toim.) (2006). The Cambridge Handbook of Expertise and Expert Performance. Cambridge university press.

Feltovich, P. J., Ford, K. M., Hoffman, R. (1997). A preliminary tour of human and machine expertise in context. Teoksessa P. J. Feltovich, K. M. Ford, \& R. R. Hoffman (toim.) Expertise in Context. Menlo Park, CA: AAAI Press, xiii-xviii.

Hakkarainen, K., Paavola, S., \& Lipponen, L. (2003). Käytäntöyhteisöistä innovatiivisiin tietoyhteisöihin. Aikuiskasvatus, 21, (1), 4-13.

Hakkarainen, K., Palonen, T., Paavola, S. \& Lehtinen, E. (2004). Communities of networked expertise. Amsterdam: Elsevier.

Hatano \& Inagaki, 1992; Desituating cognition through the construction of conceptual knowledge.

Teoksessa P. Light \& G. Butterworth (toim.) Context and cognition. New York: Harvester, 115-133.

Howells, J. (1998). Management and hybridization of expertise in network design. Teoksessa R. Williams, W. Faulkner, \& J. Fleck (toim.) Exploring expertise. London: Macmillan, 265-285.
Hutchins, E. (1995). Cognition in the wild. Cambridge, MA: MIT Press.

Knorr Cetina, K. (2001) Objectual practices. Teoksessa T. Schatzki, K. Knorr Cetina \& E. Von Savigny (toim.) The practice turn in contemporary theory. London: Routledge, 175-188.

Latour, B. (1999). Pandora's hope. Cambridge, MA: Harvard University Press.

Lave, J., \& Wenger, E. (1991). Situated learning. Cambridge, UK: Cambridge University Press.

Miettinen, R. \& Virkkunen, J. (2005). Epistemic objects, artifacts, and organizational change. Organization $12,437-456$.

Moreland, R. L. (1999). Transactive memory. Teoksessa L. L. Thompson, J. M. Levine, \&. D. M. Messick, (toim.), Shared cognition in organizations. Mahwah, NJ: Erlbaum, 3-31.

Nishiguchi, T. (2001). Coevolution of interorganizational relations. Teoksessa I. Nonaka \& T. Nishiguchi (toim.), Knowledge emergence. Oxford: Oxford University Press, 202-222

Paavola, S., Lipponen, L., \& Hakkarainen, K. (2004). Modeling innovative knowledge communities. Review of Educational Research 74, 557-576.

Palonen, T., Hakkarainen, K., Talvitie, J., \& Lehtinen, E. (2003). Heikot ja vahvat verkostosidokset ja osaamisen keskittyminen tiimityössä - esimerkkinä telealan yritysympäristö. Aikuiskasvatus, 21, (1), 14-27.

Sfard, A. (1998) On two metaphors for learning and the dangers of choosing just one. Educational Researcher 27, 4-13.

Star, S. L. (1989). The structure of ill-structured solutions. Teoksessa L. Glasser \& M. N. Huhns (toim.), Distributed artificial intelligence. Vol II. London: Pitman, 37-54.

Sverrisson, Á. (2001). Translation networks, knowledge brokers, and novelty construction: Pragmatic environmentalism in Sweden. Acta Sociologica 44 (4), 313-329.

Vygotsky, L. S. (1978). Mind in society. Cambridge, MA: Harvard University Press.

Wasserman, S., \& Faust, K. (1994). Social network analysis: Methods and applications. Cambridge University Press. 